\title{
Challenges in the Development of Systems Engineering as a Profession
}

\section{Indrajeet Dixit, USC \\ Ricardo Valerdi, MIT}

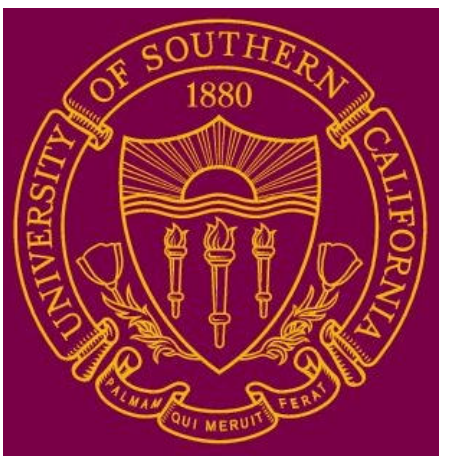

June $25^{\text {th }}, 2007$ 


\section{Agenda}

San Diego · June 24-29

- $\quad$ Professions

- $\quad$ Systems Engineering

- Central Questions

- Challenges

- Conclusions

- $\mathrm{Q} \& \mathrm{~A}$ 


\section{$D$ \\ InCOSEEOOT \\ San Diego · June 24-29}

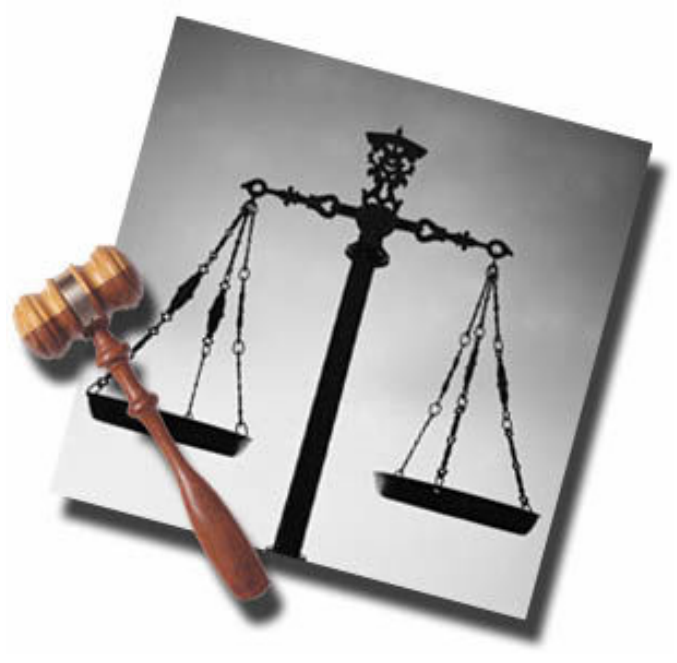

Professions

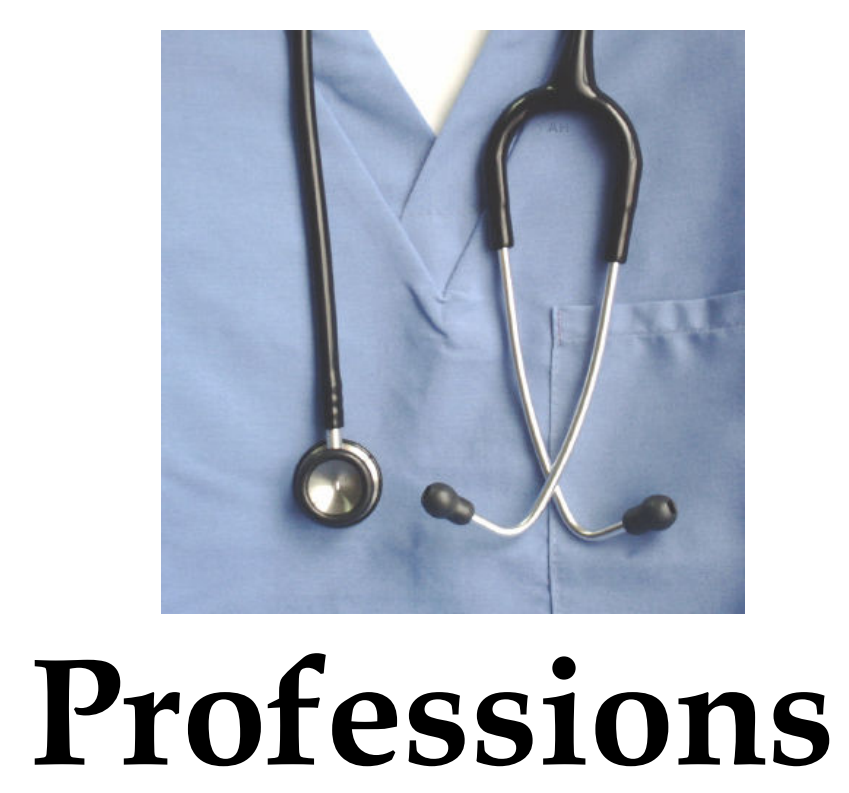

Presented to the INCOSE 2007 Symposium

\section{INCOSE \\ International Council on Systems Engineering}

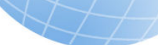

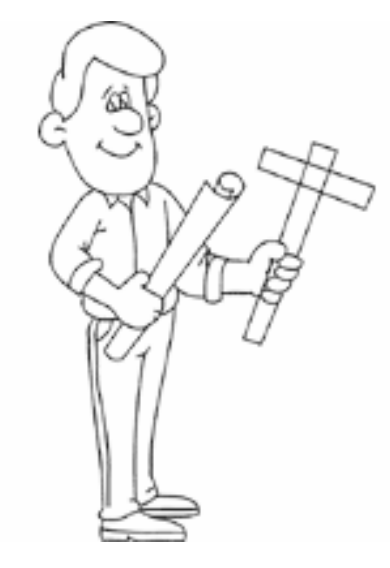

page 3 


\section{Definition}

From the Merriam-Webster Online Dictionary,

Main Entry: profession

$4 a$ : a calling requiring specialized knowledge and often long and intensive academic preparation $b: a$ principal calling, vocation, or employment $c$ : the whole body of persons engaged in a calling

Common Professions: Medicine, Law, Engineering(?) 


\section{Initial Ideas}

Inoverou

San Diego · June 24-29

- History of "Firsts"

- First journal, conference, society etc...

- Different folks, different strokes

- Power, social legitimacy etc...

- Adler and Kwon (2006): "engineering is a "semi-profession"" 


\section{"System of Professions" "INCOSE}

San Diego - June ?Y-2马

- Professionalization

- Nature of the problem

- Competition between professions

- Body of knowledge

- Abstraction in practice

- History of IEEE

- Radio vs. Power engineers

*Abbott, A., (1988), System of Professions: An Essay on the Division of Expert Labor, University of Chicago Press. 


\section{Abstraction in Practice INCOSE

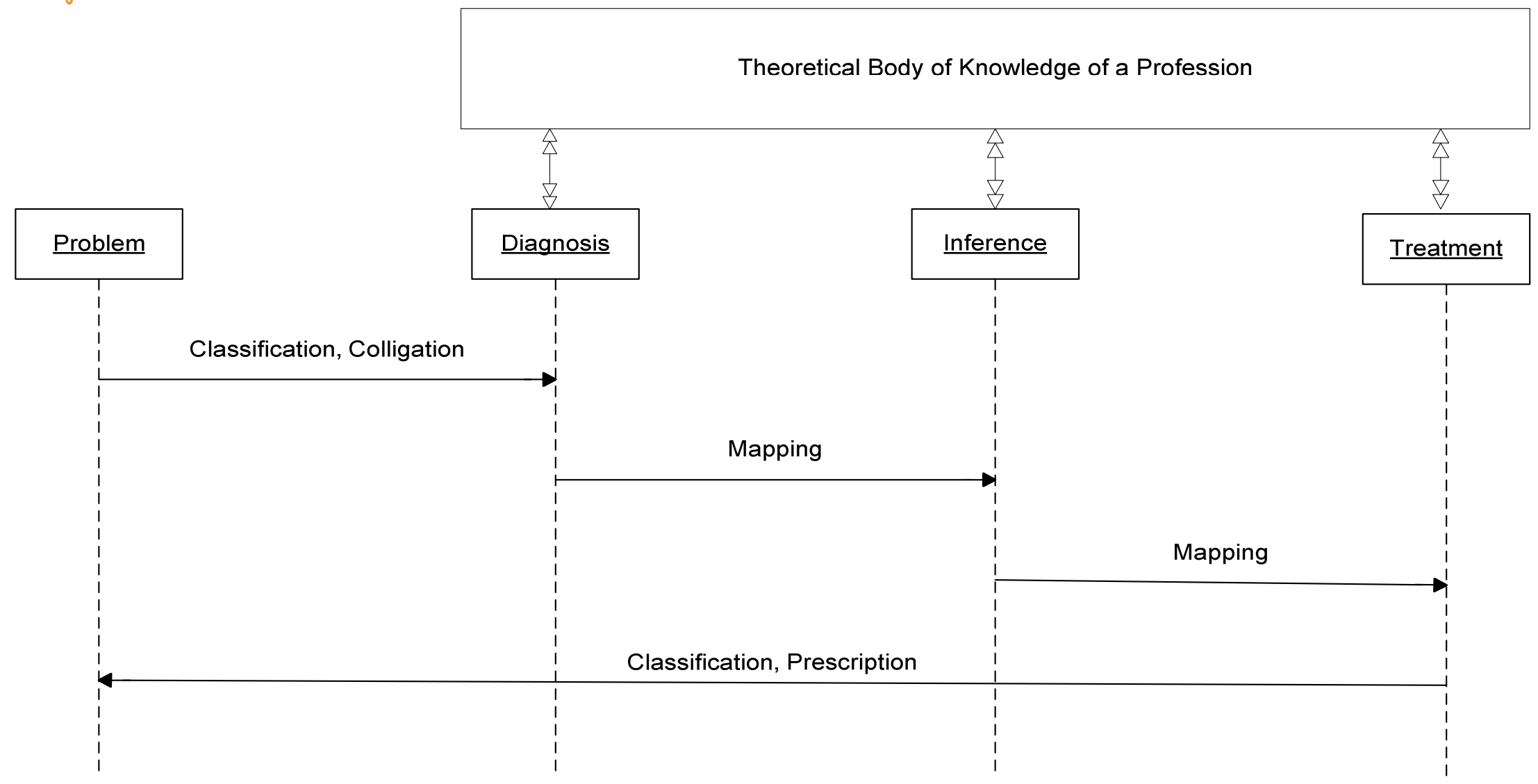

The Diagnosis-Inference-Treatment Mechanism

Presented to the INCOSE 2007 Symposium

page 7 


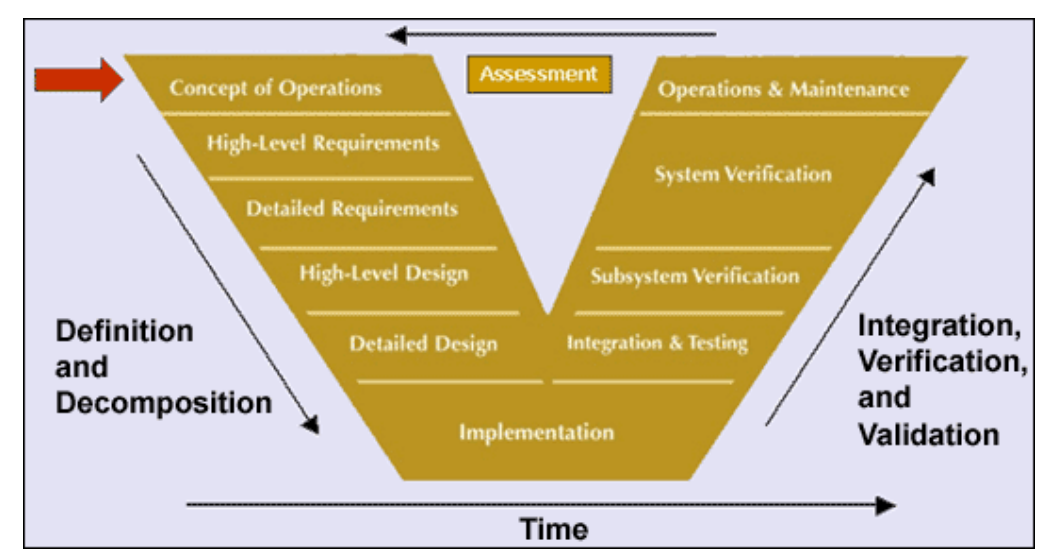

INCOSE

InCOSE2OOT

San Diego - June 24-29

\section{Systems Engineering}
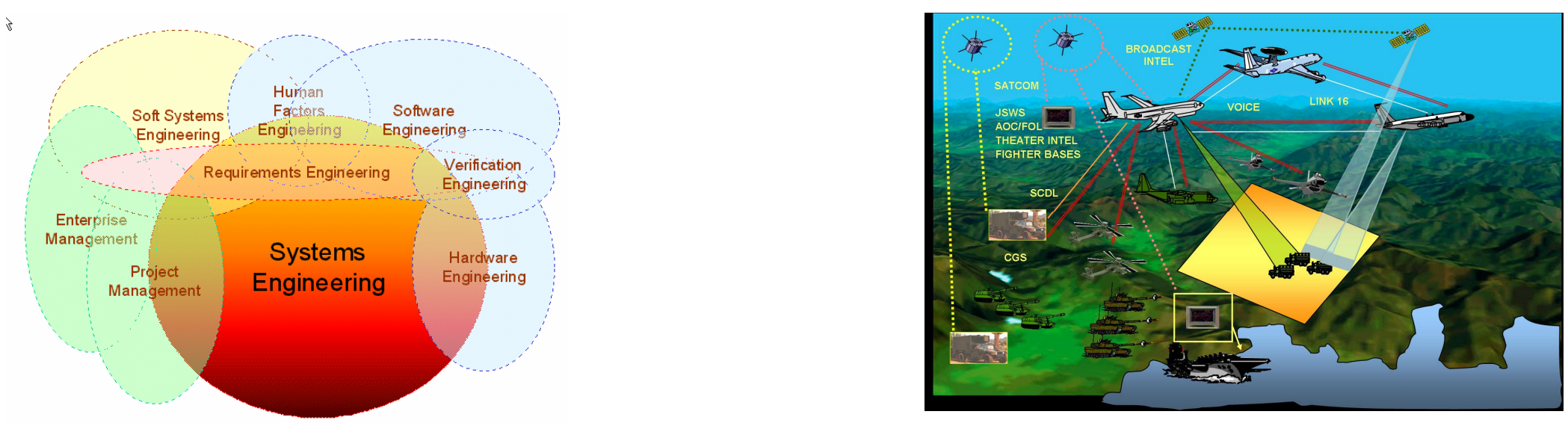

Presented to the INCOSE 2007 Symposium

page 8 


\section{Initial Ideas}

"What we've got here is failure to communicate." Cool Hand Luke (1967)

- Post-Second World War

- Bigger, larger, more complex systems

- Management of technical effort

- Response of engineers

- Several definitions/views 


\section{Current Ideas}

san Uliego · June 24-29

- Post-INCOSE

- Customer requirement

- More university programs

- Greater industry involvement

- Annual conference and journal

- Several definitions/views?

- More communication failures? 


\section{The Organization}

San Diego · June 2Y-2马

- The hierarchy of Systems Engineering

- Micro

- Specialty/Discipline Engineer

- Meso

- Senior Systems Engineer

- Macro

- Program Manager

- Every engineer does Systems Engineering

- Caveat: There is something unique in what every engineer does! 


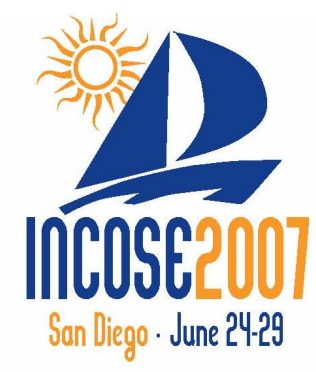

\section{Central Questions}

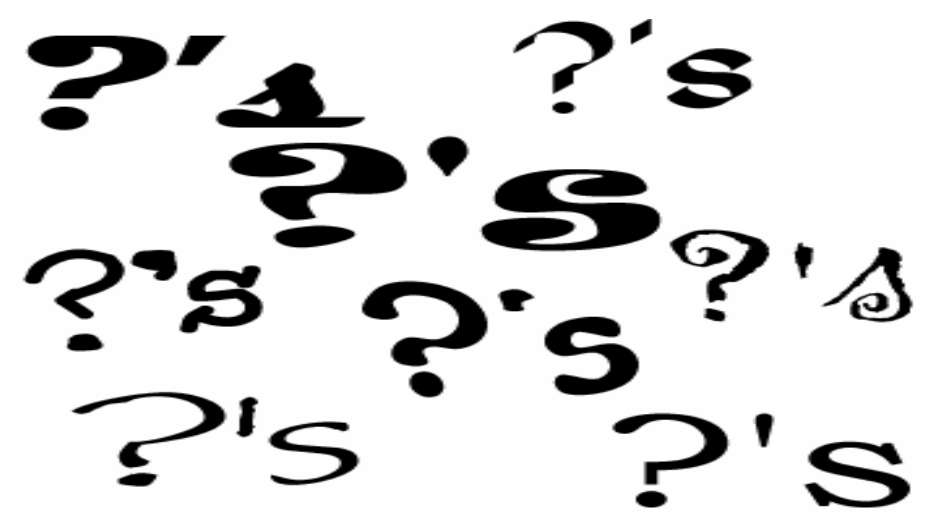




\section{Central Questions}

San Diego · June 24-29

- What is a Systems Engineering problem?

- What are the characteristics of this Systems Engineering problem?

- How does a System Engineer know what the characteristics are? 


\section{State of the Art?}

IIGJULU

san Viego · June 24-29

\begin{tabular}{|c|c|c|c|c|c|c|c|c|c|}
\hline & $\begin{array}{l}\text { Re } \\
\text { cht } \\
\text { in } \\
(19 \\
91)\end{array}$ & $\begin{array}{l}\text { Vee } \\
\text { Model } \\
\text { (Forsbe } \\
\text { rg \& } \\
\text { Mooz } \\
1995)\end{array}$ & $\begin{array}{l}\text { SE } \\
\text { Standar } \\
\text { ds } \\
\text { (ANSI/ } \\
\text { EIA } \\
1999 \text {, } \\
\text { ISO/IE } \\
\text { C } \\
\text { 2002) }\end{array}$ & $\begin{array}{l}\text { Maturit } \\
\text { y } \\
\text { Models } \\
\text { (CMMI } \\
\text { 2002) }\end{array}$ & $\begin{array}{l}\text { COSY } \\
\text { SMO } \\
\text { (Valerd } \\
\text { i et al } \\
2003 \text { ) }\end{array}$ & $\begin{array}{l}\text { DoD } \\
\text { Archite } \\
\text { cture } \\
\text { Frame } \\
\text { work } \\
\text { (DOD } \\
\text { AF } \\
2004 \text { ) }\end{array}$ & $\begin{array}{l}\text { GUTS } \\
E^{1} \\
\text { (Fried } \\
\text { man } \\
2004)\end{array}$ & $\begin{array}{l}\text { Ontologi } \\
\text { es } \\
\text { (Honour } \\
\& \\
\text { Valerdi } \\
2006 \text { ) }\end{array}$ & $\begin{array}{l}\text { VBS } \\
\text { SE }^{2} \\
\text { Jain } \\
\text { \& } \\
\text { Boeh } \\
\text { m } \\
2006 \\
\text { ) }\end{array}$ \\
\hline Observation & $\diamond$ & & & & $\diamond$ & & $\bullet$ & & $\diamond$ \\
\hline Classification & $\bullet$ & & & & $\bullet$ & & $\bullet$ & $\bullet$ & $\bullet$ \\
\hline Abstraction & $\bullet$ & & & & $\bullet$ & $\bullet$ & & & $\bullet$ \\
\hline $\begin{array}{l}\text { Quantification } \\
\& \\
\text { Measurement }\end{array}$ & & & & 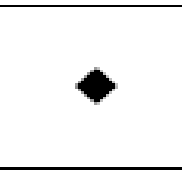 & $\bullet$ & & & & \\
\hline $\begin{array}{l}\text { Symbolic } \\
\text { Representation }\end{array}$ & & & & & & & & & \\
\hline $\begin{array}{l}\text { Symbolic } \\
\text { Manipulation }\end{array}$ & & $\bullet$ & & & & & & & \\
\hline Prediction & & & & & $\Delta$ & & & & \\
\hline
\end{tabular}

Presented to the INCOSE 2007 Symposium 


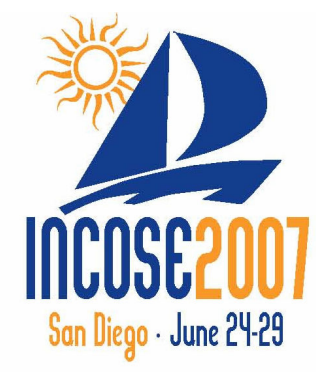

\section{Challenges}




\section{Challenges}

1. The problem space in systems engineering remains undefined

2. Lack of a coherent body of knowledge of Systems Engineering

3. The compounding effect of the lifecycle perspective 


\section{More Challenges}

4. Inability to falsify (overarching) theories of Systems Engineering

5. Lack of standard of proof in Systems Engineering 


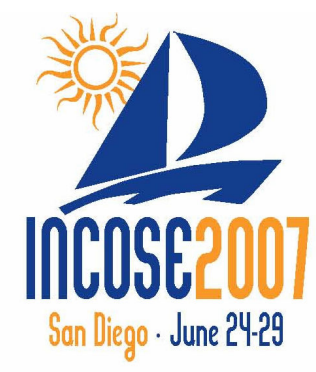

\section{Conclusions}




\section{Final Thoughts}

INCOSE

- Engineering as a Profession

- History of pragmatic problem-solving

- Problem solving preceding theoretical development

- Pragmatic usefulness, must not be lost in the quest for theorizing. 


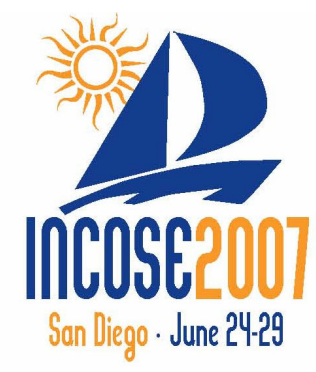

INCOSE

International Council on Systems Engineering

Q \& A

Presented to the INCOSE 2007 Symposium

page 20 